\title{
Selecting University Technology Transfer Modes:An Examination of Biotechnology Firms' Entrepreneurial Orientation
}

\author{
Dorothy M. Kirkman
}

\begin{abstract}
Universities use technology transfer to disseminate groundbreaking knowledge to biotechnology firms. Each transfer mode-licensing, sponsored contract research, and consulting arrangements —offers biotechnology firms an opportunity to acquire a unique bundle of knowledge and resources. This study proposes that an entrepreneurial orientation (EO) may influence a firm's selection of a specific technology transfer mode. An EO reflects a firm's willingness to innovate, take risks, and become a first mover. This strategic orientation may guide managers to select a transfer mode that not only fits a firm's needs but also enables it to gain an advantage. This study uses multinomial logistic regression to examine how a DBF's innovativeness, proactiveness, and risk taking influence a DBF's transfer mode selection.
\end{abstract}

Keywords: biotechnology firms; technology transfer; universities; knowledge-based view of the firm; entrepreneurial orientation; licenses; sponsored contract research; consulting agreements; drug development; multi-logistic regression. 


\section{Introduction}

Universities, as knowledge creators and disseminators, primarily utilize three forms of technology transfer to disseminate a broad spectrum of knowledge and resources to dedicated biotechnology firms (DBFs). At one end of the spectrum, DBFs use licenses to acquire and translate cutting-edge university inventions (Hoang and Rothaermel, 2010) into prototypes or patents (Rothaermel and Deeds, 2004). At the other end of the spectrum, DBFs may seek to hire university faculty as consultants, who offer advice, solve problems, or test new ideas (Perkmann and Walsh, 2008).

In the center is sponsored contract research, which occurs when a firm contracts with a university scientist to explore specific aspects of an applied problem (Perkmann and Walsh, 2007). This form of technology transfer is a combination of licensing and consulting. Contract research is similar to licensing because it might lead to the creation of new knowledge that results in a patent (Link, Siegel, and Bozeman, 2007) and it has elements of consulting agreements because it involves hiring an academic scientist to solve a problem (Tornatzky, Waugaman, and Gray, 1999). By establishing links with universities, DBFs gain access to externally conducted research that provides them with the opportunity to enhance their R\&D capabilities.

Although each mode of university technology transfer is a heterogeneous bundle of knowledge resources that provides DBFs with unique benefits, a review of university-industry studies reveals that few studies have examined the factors that motivate a DBF to select one transfer mode over other the modes. When managers select the manner in which their firm will interact with another firm, this decision influences (a) the type of relationship that will develop between the firms and (b) the type of resources that can be exchanged between them. Alliance research has explored partner selection (Bierly and Gallagher, 2007; Gulati, 1995; Li, et al., 2008a) and governance structure selection (Contractor and Ra, 2002; Coombs, Bierly, and Gallagher, 2012; Teng and Das, 2008). Since each university technology transfer mode disseminates unique forms of scientific and technological knowledge, DBFs should seek to select the mode that best fits their R\&D needs because they do not possess the slack resources to absorb a selection mistake.

This paper examines the following research question: What factors influence a DBF's selection of a university technology transfer mode? DBFs are independent, for-profit firms involved in creating human health therapies (Powell, et al., 2005). Universities are critical sourcing partners because they provide DBFs with a window to access new scientific discoveries (George, Zahra, and Wood, 2002) and each mode of technology transfer provides DBFs with a bundle of knowledge and resources they can use to complement their internal R\&D process.

To explore this question, the current paper investigates the role that an entrepreneurial orientation (hereafter EO) plays in helping DBFs select a university technology transfer mode. EO reflects a firm's ability to recognize and exploit opportunities, take risks, and experiment with novel technologies (Covin and Slevin, 1989; Miller, 1983; Wiklund, 1999; Wiklund and Shepherd, 2003). The prevailing sentiment is that a firm's EO may positively influence its performance or ability to gain an advantage (Lumpkin and Dess, 200I; Wiklund, 1999). Arguably, this advantage may extend to selecting knowledge resources.

Empirical studies reveal that an EO positively supports knowledge-based activities such as learning (Wang, 2008), innovation sourcing (Pérez-Luño, Wiklund, and Cabrera, $20 \mathrm{II}$ ), promoting innovation (Wu, Chang, and Chen, 2008), and alliance portfolio development (Marino, et al., 2002).According to Minniti and Bygrave (200I), "entrepreneurship is a process of learning" (p.7). Entrepreneurial firms foster cultures that are conducive to organizational learning (Zahra, Nielsen, and Bogner, 1999) by supporting experimentation and novel solutions to problems, doing what is necessary to achieve goals, and maintaining interorganizational relationships to secure resources (Lumpkin and Dess, 1996; Marino, et al., 2002). Entrepreneurial behaviors might motivate a DBF's managers to select transfer modes that support learning, drug development, and adaptation.

This paper uses Lumpkin and Dess' (200I) conceptualization of EO as a multidimensional construct to explore how DBFs decide to participate in a license, sponsored contract research, or consulting agreement. The multidimensional EO approach suggests that a firm can possess one or all three dimensions and be entrepreneurial. Furthermore, Lumpkin and Dess (1996, 200I) have contended that each dimension is not universally advantageous. For example, a DBF might benefit from being innovative in one situation but in another context, imitation might be advantageous. The multidimensional approach differs from the traditional conceptualization of EO as a gestalt (Miller, 1983) in which a firm must possess all three dimensions to be entrepreneurial. The current study adopts the multidimensional perspective for two reasons. First, many DBFs are resource-constrained firms and creating full-scale EO is resource-intensive (Hughes and Morgan, 2007). Second, small firms such as those in the biotechnology industry have limited resources but must still act entrepreneurially to navigate their challenging environments. This study contributes to existing literature in the following ways. There is a rich stream of alliance research that depicts how firms select alliance governance structures. This study is a novel attempt at cross-fertilization by exploring 
this phenomenon within university-industry relationships. Furthermore, existing studies either focus on the process of transferring technology from academia to industry (Cyert and Goodman, 1997; Santoro and Gopalakrishnan, 200I) or a specific mode of technology transfer such as licensing or consulting agreements (Kirkman and Phillips, 20 I2; Perkmann and Walsh, 2008; Sine, Shane, and Di Gregorio, 2003). This study concurrently examines three common forms of university technology transfer to offer insight into the unique contribution that each mode makes in supporting DBFs' drug development activities.

The next section provides a theoretical platform that explores EO and university technology transfer as knowledgebased activities and then uses this theory to develop the hypotheses in the third section. After reporting and summarizing the results, the discussion then puts forth ideas for future research, and identifies the study's limitations.

\section{Literature Review Entrepreneurial Orientation}

Entrepreneurial orientation reflects the methods, practices, and decision-making styles managers use to act entrepreneurially and may be a strategic orientation because it captures how a firm intends to compete (Lumpkin and Dess, 1996). EO highlights how managers make strategic choices that enable their firms to adapt to the environment in an effort to achieve its goals and objectives. It highlights a firm's willingness to take business risks, promote innovation, and aggressively seek opportunities in order to obtain a competitive advantage (Covin and Slevin, 1989). It is an embedded capability that resides in organizational routines and processes (Lee, Lee, and Pennings, 200I). Miller (1983) created $E O$ as a medium to assess firm-level entrepreneurial behaviors, but there is a scholarly debate concerning the nature and the composition of the construct.

On the one hand, some researchers (Covin and Slevin, 1989; Miller, 1983) have argued that EO is a unidimensional construct and the dimensions covary. This perspective suggests that a firm must possess all three dimensions originally put forth by Miller-innovativeness, proactiveness, and risk taking-to act entrepreneurially. On the other hand, some scholars (Dess, Lumpkin, and Covin, 1997; Lumpkin and Dess, 1996, 200 I) have argued that EO is a multidimensional construct and a firm does not have to possess all the entrepreneurial characteristics to engage in new entry. In support of Lumpkin and Dess' $(1996,200 \mathrm{I})$ multidimensional EO approach, Hughes and Morgan (2007) contended that the original version of EO "neglects the individual influence of each dimension and assumes a universal and uniform influence by each dimension" (p. 652). This assumption may explain the inconsistent results that emerge from over 30 years of scholarly exploration of the EO-performance relationship (Lumpkin and Dess, 200I). It is conceivable, given the mixed results, that EO may be beneficial under some conditions but not others (Hughes and Morgan, 2007).

The multidimensional approach to EO draws attention to contingency theory, which suggests that there is no one best way to organize or strategize and that organizations should make decisions that fit their circumstances (Donaldson, 200I). In a turbulent environment, adaptation is important to survival (Daft, 1989). This study employs the multidimensional approach because it promotes flexibility and adaptation. At any time, the managers of a small- or medium-sized business (SME) may have to choose which entrepreneurial activities to pursue in order to benefit the firm (Lubatkin, et al., 2006).

\section{EO Dimensions}

Research has identified innovativeness, proactiveness, and risk taking as the behaviors that highlight firm-level entrepreneurship. Innovativeness reflects a firm's propensity to engage in new idea generation, experimentation, and R\&D activities resulting in new products and processes (Lumpkin and Dess, 1996). Proactiveness reflects a forward-looking perspective where companies actively seek to anticipate opportunities to develop and introduce new products to obtain first-mover advantages and shape the direction of the environment (Hughes and Morgan, 2007). DBFs can achieve first-mover advantages (Lieberman and Montgomery, 1988) by (a) winning patent or learning races (Silverman and Baum, 2002) or (b) exploiting social connections to secure resources or gain access to alliance opportunities (Ahuja, 2000; Stram and Elfring, 2008). Risk taking highlights a firm's proclivity to support projects in which the expected returns are uncertain (Lumpkin and Dess, 1996). Interorganizational collaborations are risky endeavors because collaborating firms often have different expectations and goals that lead to conflict and missed opportunities to acquire resources and knowledge, and to learn new capabilities. DBFs that possess an entrepreneurial disposition seek to gain an advantage by creating or acquiring knowledge. Universities are often collaboration partners because they are the source of scientific discoveries in the biotechnology industry.

\section{Knowledge and University Technology Transfer}

The knowledge-based view of the firm (KBV) puts forth the notion that firms exist to coordinate and leverage specialized internal knowledge to gain an advantage (Grant, 1996). Knowledge is an important asset because firms can leverage its unique characteristics to develop and maintain an advantage. Generally, knowledge is segmented into two categories: explicit and tacit. Explicit knowledge is operational knowl- 
edge that resides in manuals or procedures (Grant, 1996). Tacit knowledge is defined as the implicit accumulation of skills that results from learning by doing (Simonin, 1999). Tacit knowledge is a valuable resource because it resides in the mind of an employee and is sticky, which makes it difficult to copy and transfer (Szulanski, 1996). It is difficult to articulate in terms that would be easily understood by others. The value of tacit knowledge is uncertain, with the highest uncertainty applying to development activities (Bercovitz and Feldmann, 2006). KBV would motivate DBFs to acquire valuable knowledge assets that it can use to create and sustain an advantage. Technology transfer offers DBFs access to academic scientists' valuable tacit knowledge.

Universities rely on their scientists whose research is typically at the frontiers of science and leads to theoretical and methodological advances and the invention of devices (Etzkowitz, 1998, p. 826). Scientists acquire knowledge through experimentation and seek to discover knowledge as an end in itself (Gieryn, 1983, p. 786). They possess knowledge stocks that consist of basic science, research "know-how" that involves their expertise in a specific scientific or technological area (Kachra and White, 2008), and latent knowledge that includes intuition about the inner workings of a technical system (Agrawal, 2006). Universities use technology transfer to disseminate this tacit knowledge to DBFs.

\section{Technology Transfer Modes}

Licenses, sponsored contract research, and consulting agreements are three common modes of technology transfer. Licenses involve selling a company the rights to use a university's inventions in return for revenue in the form of upfront fees at the time of closing the deal, and annual, ongoing royalty payments that are contingent upon the commercial success of the technology in a downstream market (Feldman, et al., 2002). When licensing an invention, a firm is purchasing know-how in the form of a patent (Agrawal, 2006). A license provides a DBF an opportunity to develop an invention that is protected by a patent. By doing so, the firm can benefit from the temporary right to exploit new knowledge without any competition. Sponsored contract research occurs when a faculty member agrees to accomplish specific research, and the company agrees to pay the university to do so (Tornatzky, Waugaman, and Gray, 1999). When sponsoring a faculty member's research, a DBF gains access to a team's research expertise that results from a combination of years of research experience, faculty expertise, and administrative and other processes (Markman, Siegel, and Wright, 2008). Consulting arrangements occur when a firm hires an academic scientist to perform a service. Hiring a university faculty member as a consultant provides DBFs with opportunities to acquire the scientist's tacit knowledge through frequent interactions (Perkmann and Walsh, 2008) as well as offers them access to new scientific ideas and trends (Niosi, 2003).

In summary, EO is a strategic posture that encourages DBFs to engage in advantage-seeking behaviors by taking risks and doing things differently. Since it may take nearly decade to profit from their R\&D investments, DBFs with an entrepreneurial disposition might be able to leverage their capabilities to secure the resources that are necessary to survive. The following discussion presents the hypotheses.

\section{Hypotheses Innovativeness}

The development of new products involves extensive and intensive knowledge activities (Li, et al., 2008b) that require DBFs to possess and gain access to a broad range of knowledge in order to become competitive (DeCarolis and Deeds, 1999). To innovate, DBFs make significant investments in the "R" part of R\&D (Zahra, 1996), which involves exploration - the pursuit of knowledge, of things that might come to be known (Levinthal and March, 1993, p. 105). During the exploration process, innovative firms solve problems, learn, and create new knowledge and capabilities. In innovative DBFs, managers support novel problem solving, encourage employees to embrace new ideas (Abbey and Dickson, 1983), and discard old ways of doing things.

Given innovative DBFs' focus on exploring new knowledge and exploring new ways of doing things, these DBFs might not sponsor faculty research. Innovative DBFs possess exploratory capabilities that allow them to perform novel research without faculty assistance. These firms might be more attracted to licenses because most university inventions are acquired in the early stage when significant development work is required (Agrawal, 2006; Cohen, Nelson, and Walsh, 2002). Innovative DBFs possess the capabilities to make sense of the core technologies used to create a university invention and then transform it into a replicable prototype that can be licensed out or used as the basis to form a joint development project with pharmaceutical firms.

Although an innovative DBF might not sponsor faculty research, it may use consulting agreements to secure support when solving complex research problems. Research has revealed that consulting agreements helped firms complete existing projects (Cohen, Nelson, and Walsh, 2002).

\section{Therefore,}

Hypothesis I: Innovative DBFs are more likely to participate in licensing and consulting agreements than sponsored contract research. 


\section{Proactiveness}

Proactive DBFs continuously scan the market looking for technological opportunities to help them become a first mover and gain entrepreneurial advantages. For a DBF to recognize a valuable technology, it must possess a certain level of technological capabilities. Kirzner (1979) called this phenomenon entrepreneurial alertness, or the spontaneous process in which individuals differ in their capacity to identify or recognize opportunities. At the firm level, this phenomenon refers to absorptive capacity (Cohen and Levinthal, 1990) or an organization's ability to identify and leverage external knowledge.

Licensing is a transfer opportunity that allows DBFs to exploit their prior knowledge to gain access to an invention that will help the firm secure an advantage or profits (Stuart, Ozdemir, and Ding, 2007). Exploitation involves leveraging those routines and behaviors that underlie current competencies (Lubatkin, et al., 2006). A DBF's prior experience working with a technology or exploring a specific scientific area implies that a firm has the capabilities to develop this technology and it will not shelve it or shirk its developmental responsibilities (Dechenaux, Thursby, and Thursby, 2009). Searching for first-mover opportunities, proactive DBFs might also be attracted to sponsored contract research. Sponsored research provides a DBF access to a university's lab (Tornatzky, et al., 1999), graduate students as potential new hires (Perkmann and Walsh, 2007), and the ability to acquire newly developed knowledge in the form of new processes and technologies that can be used as inputs to develop new projects. Sponsored contract research offers DBFs opportunities to acquire new knowledge to gain an advantage in the future while licensing offers DBFs an opportunity to gain an advantage today.

Therefore,

Hypothesis 2:A DBF's proactiveness is more strongly associated with licensing and sponsored contract research than with a consulting agreement.

\section{Risk Taking}

Firms with a propensity for risk taking move boldly into new and uncertain ventures (Lumpkin and Dess, 1996). Without a propensity to take risks, a firm's management team may wait to act on a new venture until all the uncertainty has dissipated. Licensing and sponsored contract research include a high level of uncertainty. Regarding licensing, there is no guarantee that the university invention has commercial potential. A DBF can pay fees only to discover they have acquired a "lemon" license. Jensen, Thursby, and Thursby (2003) argued that high-quality faculty possess the ability to secure fund- ing without pursuing commercial activities; therefore, some inventions may be lacking in quality.

When sponsoring faculty research, the tacit nature of the output makes it difficult to administer and control the interaction by using a contract (Howells, Gagliardi, and Malik, 2008). Incomplete contracts can lead to adverse selection and moral hazard problems. Adverse selection refers to the misrepresentation of ability by the agent (Eisenhardt, 1989). For example, junior faculty members may actively pursue industry research contracts but lack experience using basic science to solve industrial problems (D'Este and Perkmann, 20II). Moral hazard involves the sellers' decision to pursue their agenda (Dechenaux, Thursby, and Thursby, 2009) by taking the output generated while working with one client and using it, without permission, when working with another firm (Howells, Gagliardi, and Malik, 2008).

Conversely, consulting agreements may be less risky because (a) a DBF does not have to make an investment before acquiring academic knowledge, (b) these arrangements are often short-term (Agrawal, 2006), and (c) scientists can use their existing knowledge to offer advice (Dechenaux, Thursby, and Thursby, 2009), thereby reducing the possibility of adverse selection.

Based on this argument,

Hypothesis 3:A DBF's risk taking is more strongly associated with a sponsored contract research and licensing agreement than a consulting agreement.

\section{Methods \\ Setting and Sampling Frame}

The biotechnology industry is the setting for this study. By definition, biotech is knowledge intensive, which means that the complementary processes of discovery and innovation necessitate the union of assets that characterize different types of organizations-both public and private (Feldman, et al., 2002). Drug development requires information from a variety of interorganizational interactions (Bercovitz and Feldmann, 2006). University discoveries played a major role in the founding of the industry and remain a critical source of new knowledge (Prevezer, 1997). The sampling frame for this study included biotechnology firms located in the United States. This research focuses on domestic firms because most of the commercialized biotechnology products emerged from the United States (Shan and Song, 1997).

A three-step process was employed to identify firms in the sample. First, a list of potential respondents was drawn from nonprofit biotechnology associations' directories and HOOVERs business data to access publically traded firms. 
This step identified I,000 potential respondents. The second step involved classifying biotechnology firms by their North American Industry Classification Scheme codes. Those NAICS codes that emphasized research and development of human health biotechnology products (NAICS 3254II: Medicinal and botanical manufacturing; NAICS 3254I4: Other biological product manufacturing; and NAICS 54I7I0: Physi$\mathrm{cal}$, engineering and biological research) were identified as the most useful and appropriate. Biotechnology studies (Rothaermel and Deeds, 2004) have examined phenomena in therapy- or drug-producing DBFs because these firms encounter specific resources and regulatory challenges when commercializing new products (Hoang and Rothaermel, 2005). These challenges lead biotechnology firms to seek external knowledge. In the third step, each firm's phone number, address, and NAICS code was verified using Reference USA (now called A-to-Z database), a library search engine that contains 12 million business listings and includes address, firm size, founding date, and NAICS codes. After verification of each firm's information, the final sample included 838 biotechnology firms.

\section{Data Collection}

Because technology transfer mode selection has received scant attention, a multimethod approach was used to collect data. Semistructured interviews were conducted with directors of technology transfer offices (UTTOs) at five U.S. universities. Since many DBFs emerged from academic settings, interviews with UTTO directors provided an understanding of specific technology transfer modes and how DBFs use them to address their strategic needs. Third, literature reviews were conducted following interviews and scales were selected.

A questionnaire was used to collect data for variables in this study. Since the questions focused on the firm's technology strategy, the questionnaire was mailed to the senior executive responsible for R\&D, such as president and CEO, vice president of R\&D, or vice president of scientific discovery. In small firms, the head of R\&D is the primary source and perhaps the only source that is knowledgeable about the firm's transfer activities (Norburn, 1989). The following profile of responding DBFs emerged (some of the profile variables were not included in this study): The responding firms were 9 years old, $77 \%$ were located in biotechnology clusters, $75 \%$ were founded by academic scientists, $40 \%$ had prior links with their current university partner, and $68 \%$ were private firms that spent $\$ 10.2$ million in R\&D over a 3-year period. The average responding firm participated in 10 university linkages in 5 years (2.5 sponsored contract research, 2.5 licensing agreements, and 4.6 consulting agreements).
The questionnaire was administered using Dillman's (1978) method of mail survey response and design, which suggests that researchers send pre-notification letters, a questionnaire package, and several follow-up reminders to potential respondents to increase survey response rates. A retired R\&D executive provided advice regarding the content of the pre-notification letters, questionnaire package, and reminders. Three mailings, sent 6 weeks apart, were administered to collect questionnaire responses. The lag time between the mailings was necessary to collect responses and update the database with new firm information. A total of 990 surveys were mailed to eligible respondents. The distribution of the mailings is as follows: 680 surveys sent in the first mailing, 225 in the second mailing, and 85 in the final mailing. In total, 204 responses were received but six were deleted due to missing data, leaving 198 responding firms. This analysis includes $17 \mathrm{I}$ of the responding firms because 27 firms did not participate in university-industry interactions.

The survey administration achieved a response rate of $19.8 \%$, which compares favorably with survey response rates of other studies of small firms-for example, 15\% (Lee, Lee, and Pennings, 200 I). Studies of small firms typically have low response rates because the CEO must personally respond to the survey since there are few others knowledgeable enough to assume the task (Bartholomew and Smith, 2006). In survey research, the timing or lack of responses from certain groups is important and may increase the potential of a response bias. Some researchers analyzed early and late responses using $t$ tests, which are used to identify significant differences between two groups of respondents. Linder, Murphy, and Briers (200I) conducted meta-analysis studies which revealed that II4 (37.5\%) of the 304 studies conducted used some form of nonresponse analysis. The degree of nonresponse bias depends on two factors: the percentage of the sample that does not respond and the extent to which nonresponders differ systematically from the study population (Barclay, et al., 2002). I used t tests to determine whether there was any nonresponse bias in my study.

I conducted an independent-sample $t$ test to compare public firms that responded to the survey and public firms that did not respond. I compared the two groups by comparing the means of public firms that responded and means of public firms that did not respond. I used firm size because it is easy to obtain such data from public online sources. The findings of this $t$ test revealed no significant difference in firm size for responding public firms $(M=146.40, S D=259.59)$ and nonresponding public firms $(M=104.60, S D=121.94)$. Additional $t$ tests were conducted to assess bias among late and early respondents. These results are consistent with findings of Linder et al's (200I) meta-analysis of survey research. The analysis revealed that found $75 \%$ of studies they analyzed exhibited no differences between early and late respondents. The results from additional $t$ tests are listed in Table $I$. 


\begin{tabular}{|c|c|c|c|c|c|}
\hline Firm & $n$ & $M$ & $S D$ & $T$ & $\begin{array}{c}\text { Equality of } \\
\text { Means } \\
\text { Sig (2-tailed) }\end{array}$ \\
\hline \multicolumn{6}{|l|}{ Public Firms } \\
\hline Responding public & 65 & 146.40 & 259.53 & 1.08 & 0.38 \\
\hline Nonresponding public & 53 & 104.60 & 121.95 & & \\
\hline \multicolumn{6}{|l|}{ Innovativeness } \\
\hline Early responders & 167 & 22.70 & 2.08 & .333 & 0.740 \\
\hline Late responders & 31 & 21.69 & 2.41 & & \\
\hline \multicolumn{6}{|l|}{ Total R\&D Projects } \\
\hline Early responders & 167 & 7.17 & 9.99 & .083 & 0.934 \\
\hline Late responders & 31 & 7.30 & 10.78 & & \\
\hline \multicolumn{6}{|l|}{ R\&D Spending } \\
\hline Early responders & 167 & $\$ 11.3 \mathrm{M}$ & $\$ 20.3 \mathrm{M}$ & .437 & 0.663 \\
\hline Late responders & 31 & $\$ 9.87 \mathrm{M}$ & $\$ 21.6 \mathrm{M}$ & & \\
\hline
\end{tabular}

Table I.Assessment of Response Bias Using t Test.

\section{Measures}

The survey was pretested with MBA alumni and pilot tested at three biotechnology firms. The survey was revised based on the pretest and pilot test responses. Pilot DBFs were excluded from the final survey administration. The pretest and pilot test feedback focused on cosmetic issues such as length, white space, and order of the scales. The questions are listed in Table 2.

\section{Dependent Variable}

Technology transfer mode reflects a DBF's preferred university technology transfer mode. Respondents were asked to identify their firm's preferred form of university technology transfer from a list that included licensing, sponsored contract research, consulting agreements, and not applicableno university links. There was one preferred mode of university technology transfer associated with each responding firm. Each responding firm's preference was recoded into a categorical variable, with licenses coded as I, sponsored contract research coded as 2 , and consulting agreements coded as 3 .

- $\quad$ Licensing agreements involve selling a company the rights to use a university's inventions in return for revenue in the form of upfront fees at the time of closing the deal and annual, ongoing royalty payments contingent upon the com- mercial success of the technology in a downstream market (Feldman, et al., 2002, p. 107).

- $\quad$ Consulting agreements constitute an arrangement in which a faculty member accepts an engagement, on a private basis, with a company that needs expert advice (Tornatzky, Waugaman, and Gray, 1999, p. 20).

- $\quad$ Sponsored contract research pertain to a single project or a group of closely related research tasks sponsored by one company at one university. The university agrees to accomplish specific research, and the company agrees to pay the university to do so (Tornatzky, Waugaman, and Gray, 1999, p. I3).

\section{Independent Variables}

Entrepreneurial orientation reflects the extent to which top managers are inclined to take business-related risks, to favor change and innovation in order to obtain a competitive advantage for their firm (Covin and Slevin, 1989). This study uses a resource-based conceptualization of EO, which is consistent with Lyon, Lumpkin, and Dess' (2000) analysis of the EO construct and related research. A resource-based approach reflects the notion that resources drive both strategic and entrepreneurial behavior.Various resource conceptualizations of EO have been used. Pérez-Luño,Wiklund, and Cabrera (20II) operationalized innovativeness by assessing 
the number of new products a firm had created over the last 5 years. Hitt, Hoskisson, and Kim (1997) used R\&D intensity as a proxy for innovation. Resource-based measures tend to have high reliability; however, issues may arise regarding the validity of the measure (Lyon, Lumpkin, and Dess, 2000). To address possible validity concerns, three reviewers rated the measures to determine content validity. Reviewer \#I is a distinguished professor in biotechnology at a Research I university. Reviewer \#2 has been involved with three startup firms and currently owns a biotechnology-consulting firm. Finally, Reviewer \#3 is currently the CEO of a start-up biotechnology firm.

I conducted a literature review and identified three measures that had been used to assess a firm's innovativeness, proactiveness, and risk taking. The measures and their descriptions were sent to the reviewers, who rated the measures using a Likert-type scale ranging from 5 (relevant) to I (not relevant). Since each reviewer was located in a different part of the country, there was no group consensus used to identify the most appropriate measure. The measures used in this study each received a rating of 5 from each reviewer. Their feedback indicated that the measures used in this study accurately reflected actual industry practices. In addition, a factor analysis was conducted to determine the validity of the scales. The analysis produced three factors, each with an eigenvalue over I, which accounted for $42 \%$ of the variance. The highest factor accounted for $18 \%$ of the accumulated variance. Since the first factor did not explain the majority of the variance in the variables (Podsakoff \& Organ, 1986, p. 536), common method bias was not a significant concern. The EO measures are listed below.

Innovativeness highlights a firm's use of methods through which new ideas, routines, or prototypes are developed (McFadyen and Cannella, 2004). In this study, patents were used to assess a firm's innovativeness. Patents have been widely used as a proxy for knowledge creation and innova-

\begin{tabular}{|c|c|}
\hline Variables & Survey Questions \\
\hline $\begin{array}{l}\text { Technology Transfer } \\
\text { Mode }\end{array}$ & $\begin{array}{l}\text { - What form of university technology transfer does your firm prefer (Please } \\
\text { Select One): (a) Licensing, (b) Sponsored Contract Research, (c) Consulting } \\
\text { Agreements, (d) Not Applicable (No University Links) }\end{array}$ \\
\hline Innovativeness & $\begin{array}{l}\text { - How many approved patents _ and patent applications__ are associated with } \\
\text { your firm? }\end{array}$ \\
\hline Proactiveness & $\begin{array}{l}\text { - Please indicate the number of projects your firm currently has in clinical devel- } \\
\text { opment: } \\
\text { - Phase I: First testing of a potential new drug or therapy in 20-80 human } \\
\text { subjects. } \\
\text { Phase II: Large group testing (100-300) of the drug or therapy's effective- } \\
\text { ness and safety. } \\
\text { Phase III: Large group testing (1000-3000) to determine the drug or ther- } \\
\text { apy's effectiveness, monitor side effects, and collect data that will allow the } \\
\text { drug or treatment to be used safely. } \\
\text { - Projects approved by the FDA. }\end{array}$ \\
\hline Risk Taking & $\begin{array}{l}\text { number): } \\
\text { - } \frac{\text { Projects using the same underlying core technology that can be }}{\text { projects. }} \text { Projects using unique technologies that cannot be used in other } \\
\text { - How old is your firm (Please estimate)? a. Years _ b. Months _ }\end{array}$ \\
\hline $\begin{array}{l}\text { Age } \\
\text { Licensing Term }\end{array}$ & $\begin{array}{l}\text { - What were the terms of your firm's most recent licensing agreement? (a) Exclu- } \\
\text { sive (b) Non-Exclusive } \\
\text { - Prior to your most recent university above collaboration, did you have a rela- }\end{array}$ \\
\hline $\begin{array}{l}\text { Previous Relation- } \\
\text { ship }\end{array}$ & $\begin{array}{l}\text { - } \quad \text { Estimate your R\&D spending (in USD millions) 2003-2005. }\end{array}$ \\
\hline R\&D Spending & \\
\hline
\end{tabular}

Table 2. Survey Items for Independent and Dependent Variables.

ISSN: 07 I8-2724. (http://www.jotmi.org)

Journal of Technology Management \& Innovation (C) Universidad Alberto Hurtado, Facultad de Economía y Negocios. 
tion because they capture output from a firm's technological capabilities (DeCarolis, 2003). Innovativeness was measured using Deeds' (200I) assessment of a firm's exploratory or inventive capabilities. The following measure was used during hypotheses testing: Early Stage Technology Development $=$ Sum ( $\mathrm{n}$ of patents pending $+\mathrm{n}$ of patents approved). The patents and patent applications were collected over a 5-year period due to the lag between patent applications and patent approvals. The Chronbach alpha for this measure is 0.81 . Proactiveness refers to a firm's propensity to be a "leader rather than a follower given its willingness and foresight to seize new opportunities" (Walter,Auer, and Ritter, 2006, p. 9). In the biotechnology industry, this reflects a firm's ability to transform knowledge into commercial products. It includes their ability to make it through the clinical trials process. All potential drug candidates that can improve human health go through a rigorous three-stage clinical trial process. The therapy progresses through a small trial that focuses on the safety of the drug in Stage I to large-scale testing in Stages II and III that assess whether the drug works as intended. To measure this dimension, I used Deeds' (200I) technological capability development measure. The following measure was used during hypotheses testing: Late Stage Technology Development $=$ Sum ( $n$ of products in Stage $\mathrm{I}+\mathrm{n}$ of products in Stage II $+n$ of products in Stage III $+n$ of products approved). The Chronbach alpha for this measure is 0.79 .

Risk taking is a reflection of the diversity of a firm's technology portfolio (Zahra, 1996). The diversification measure was computed using the Blau Index of Variability (Blau, 1977), which is often used in alliance studies (Jiang, Tao, and Santoro, 20I0). To determine the diversity of a variable: $D=$ I $\square \square$ pi2, where $D$ is the degree of diversity, p represents the proportion that belongs to a given category, and $i$ is the number of different university links. When $D$ is close to I that means the category being assessed is very heterogeneous; when $D$ is close to 0 the category is homogenous. To assess a firm's risk, the respondents were asked to categorize the core technologies used in the firm's projects, in terms of using new and existing technologies, and the total number of projects in their R\&D pipeline. The Chronbach alpha for this measure is 0.86 .

\section{Control Variables}

Age refers to the number of years that have passed since the firm was established (Wiklund, 1999). Cluster refers to the geographical location of the biotechnology firm (Casper, 2007). Since the origin of the U.S. biotechnology industry, firms have been known to develop around centers of excellence (Chiesa and Chiaroni, 2005). The zip code for each response was logged when received and then compared to the Metropolitan Statistical Analysis (MSA), or groups of zip codes, that represent the top 10 biotechnology clusters listed in Ernst and Young's 2005 Annual Biotechnology Report. The MSA used in this study includes the Census Bureau population estimates for July I, 2006. This cluster variable is a predictor where I represents cluster-located DBFs and 0 reflects noncluster DBFs. Licensing term reflects the various forms of the licensing agreement. There are two basic forms of licensing: exclusive and nonexclusive (Markman, et al., 2005). An exclusive license gives a DBF sole permission to develop a technology. When a DBF acquires a nonexclusive license, it may be included in a group of firms that acquire a specific technology from a university. This scale includes a dummy variable where I represents an exclusive license and 0 reflects a nonexclusive license.

Previous relationship refers to whether a DBF had a prior relationship with its most recent university partner. Zahra (1996) used this variable when examining technology strategy in biotechnology firms to control for relational benefits that accumulate to firms that have a history of trust and competency development. This construct is measured using a dummy variable that is coded with a $I$ if the firm had a previous relationship with its most recent university partner and 0 if it did not. R\&D intensity is computed by taking the ratio of R\&D expenditure to the number of employees. Many empirical studies have shown university-firm linkages positively influence a firm's inventive performance (Cockburn and Henderson, 1998; Zucker, Darby, and Torero, 2002). These studies controlled for the R\&D investment or scale in order to isolate the impact of university collaboration and internal research activities on a firm's inventive process. Traditionally, the measure is calculated by dividing the R\&D investment by spending. However, many biotechnology firms do not have any sales; therefore, the number of employees is utilized as a means of capturing the scale effect of R\&D spending. This measure is a log of the ratio of a firm's total spending in R\&D versus the number of full-time employees, which adjusts for differences in spending based on company size (George, Zahra, and Wood, 2002). Table 2 lists the survey questions.

\section{Results}

Table 3 lists the correlations and descriptive statistics for the variables used in the current study. The highest relationship in the correlation table is between previous relationship and exclusive licensing $(r=.53, p=.01)$. This relationship suggests that DBFs that had a previous relationship with a university were more likely to obtain an exclusive licensing option, which provides the DBF with sole rights to develop and profit from the technology or a quasi-monopoly option. A university needs to be familiar with a licensee before awarding them sole rights to acquire a profit-generating asset. Research suggests that familiarity engenders trust (Gulati, 1995). 


\section{Hypotheses Testing}

Multinomial logistic regression (MLR) was used to assess the hypotheses. MLR is often used to determine the likelihood of a DBF selecting a type of university collaboration given a specific set of predictors or covariates. This procedure is a variation of logistic regression that is used when the dependent variable is categorical and has more than two values (Baum, Schwens, and Kabst, 20II). MLR uses a categorical variable as the dependent variable, and one of the dependent categories is selected as a reference group. In the current study, licensing was selected as the reference category because it had the highest frequency among the technology transfer modes: licensing (67), consulting agreements (64), sponsored contract research (34), not answered/no university links (33).

MLR describes how the chance of belonging to a group other than the reference category is influenced by predictor variables (Baum, Schwens, and Kabst, 20I I). Agarwal and Ramaswami (1992) used MLR to examine how ownership, location, and internationalization advantages influence the choice of foreign market entry mode, and Baum, Schwens, and Kabst (20II) used MLR to explore internationalization choices in new ventures. Given the use of MLR in previous studies, this is an appropriate method to evaluate how entrepreneurial capabilities help a DBF's managers decide which mode of university technology transfer to select. Table 4 presents the results for testing Hypotheses I and 2. Table 5 lists the analysis for Hypothesis 3 and the full model. There are two panels in each table. The first panel lists sponsored contract research as the selection that is compared to licensing. In the second panel, consulting agreement is the selection that is being compared to licensing.

Hypothesis I predicts that an innovative DBF will be more likely to choose licensing agreements and consulting arrangements over sponsored contract research. The results are listed in Table 4, Model I. In Pane I I the coefficient of innovativeness is negative $(B=-0.54, p<.10)$, which suggests that non-innovative firms are more likely to select sponsored contract research over licensing. Examining the "EXP $B$," which reflects the odds ratio of the predictors, suggests that non-innovative DBFs are almost 2 times more likely to select contract research over licensing. To rephrase the results in language of the hypothesis, a DBF with a higher innovativeness score is more likely to prefer licensing to sponsored research than DBFs with lower innovativeness scores. As hypothesized, innovative firms avoid sponsored contract research because they possess the capabilities to conduct the research internally.

In Panel 2, the MLR results show that non-innovative DBFs are more likely to choose consulting agreements over li- censing. The coefficient of innovativeness is negative $(B=$ $-0.512, p<.10$ ), which suggests that non-innovative firms are more likely to select consulting agreements over licensing. Non-innovative DBFs are I.3 times more likely to select consulting agreements over licensing, which is contrary to the hypothesized argument. The results show that innovative firms seek to license technologies from universities while non-innovative firms hire faculty as consultants and sponsor faculty research. This hypothesis was partially supported.

Hypothesis 2 asserts that a proactive DBF will be more likely to choose licensing agreements and sponsored contract research over consulting agreements. The results are listed in Table 4, Model 2. In Panel I, the findings show that proactive DBFs $(B=0.75, p<.05)$ are 1.8 times more likely to select sponsored contract research over licensing. In Panel 2, the analysis reveals that non-proactive DBFs $(B=-0.86, p<.05)$ are 2.3 times more likely to select consulting agreements over licensing. In other words, as a DBF's proactiveness increases one unit, it is 2.3 times less likely to select consulting agreements over licenses. As a firm becomes more proactive, it is predisposed to select licenses over consulting agreements. This hypothesis was fully supported.

Hypothesis 3 proposes that DBFs that are willing to take risks are more likely to choose sponsored contract research and licensing agreements over consulting arrangements. Table 5, Model I contains the results, which were mixed. In Panel I, the analysis shows that risk-taking DBFs $(B=.42, \mathrm{p}<$ $.05)$ are 1.5 times more likely to select sponsored contract research over licensing. Contrary to the argument put forth, the findings listed in Panel 2 indicate that risk-taking DBFs (B $=.67, p<.10$ ) are more likely to choose consulting over licensing. Those DBFs that are willing to move forward under uncertain and ambiguous conditions select modes of technology transfer that contain high levels of tacit knowledge, which is vague because it resides in the scientist's mind. Risktaking DBFs are betting that contract research and consulting will provide them with valuable tacit knowledge that can enhance their R\&D capabilities.

Finally, Table 5, Model 2 presents the analysis of the full model that includes all the EO dimensions. In Panel I, a DBF that is risk-taking $(B=0.44, p<.10)$ and proactive $(B=0.97, p<$ $.00 \mathrm{I})$ is more inclined to sponsor faculty research than acquire a license. Panel 2 reveals that when all the EO dimensions are present, only proactiveness significantly influences a DBF's selection of consulting agreements over licensing. The findings in the full model support Hughes and Morgan's (2007) argument that the EO dimensions do not uniformly influence the outcome. In specific context (Lumpkin and Dess, 200I) such as deciding whether to acquire a license or hire a faculty member as a consultant, the results suggest that proactiveness is the dimension that matters. In sum- 
mary, the results fully supported Hypothesis 2 and partially supported Hypotheses I and 3.

\section{Discussion}

The purpose of this study was to explore how EO dimensions influence a DBF's selection of technology transfer mode. This goal may appear to be simplistic, but it draws attention to DBFs as autonomous organizations that make strategic sourcing decisions. This focus on strategic choices made by DBFs is important to our understanding of how DBFs grow and develop. Many DBFs were formed to commercialize the scientific explorations (Powers and McDougall, 2005) of star scientists (Toole and Czarnitzki, 2007; Zucker and Darby, 200I). New DBFs have a limited history of collaborations and represent a moral hazard in terms of their ability to contribute valuable resources to a partnership (Gulati, 1999). Baum and Silverman (2004) proposed, "because startups encounter so many hazards and because they have short-track records by which outsiders can evaluate their potential, there is considerable uncertainty about their value" (p. 4I5). These firms rely on their links with universities to acquire resources, establish their legitimacy, and secure informal university support (Rothaermel and Thursby, 2005).

Being unattractive collaboration partners, establishing links with universities to acquire resources may be the only option available to new DBFs. Their inability to secure resources determines the choices that are available to managers (Astley and Van de Ven, 1983). By collaborating with universities, new DBFs can survive and compete in a rapidly changing industry. In contrast to this deterministic perspective, the strategic choice perspective suggests that organizations are not held hostage in a reactive-adaptive prison (Bourgeois, 1984) where their choices are simply determined by their environments (Thompson, 1967). Organizations can and do make choices that involve goals, domains, technologies, and structural variables (Child, 1972). Conceivably, as DBFs make strategic choices to foster their growth and development, their relationships with universities change from being solely rooted in dependency to supporting goal attainment. According to a UTTO director.

Biotechnology firms seek out universities that have resources that fit their strategic needs. This link depends on the uniqueness of the university's resources and how a firm can use them (UTTO director at a university in the U.S. Midwest, personal communication, December 27, 2005).

By focusing on selection, my research seeks to connect to governance mode selection studies in alliance literature that investigate the many ways in which firms can acquire external knowledge, each of which reflects firms' different priorities or circumstances (Van de Vrande, Vanhaverbeke, and Duysters, 2009). Because there are unique benefits associated with specific sourcing strategies (Nicholls-Nixon and Woo, 2003), identifying appropriate transfer vehicles should enable DBFs to acquire knowledge to support their product development activities. This discussion will now summarize the results to provide insight on how a DBF's entrepreneurial orientation influences its transfer mode selection.

\section{Results Summary}

Several insights emerged when reviewing the results of this study. First, non-innovative DBFs select technology transfer modes in which they can use the expertise of university faculty as a substitute for their lack of R\&D capabilities. Hypothesis I asserts that innovative DBFs would select licensing and consulting agreements over sponsored contract research. The mixed results revealed that non-innovative

\begin{tabular}{|c|c|c|c|c|c|c|c|c|c|c|c|}
\hline & Mean & Std. Dev. & 1 & 2 & 3 & 4 & 5 & 6 & 7 & 8 & 9 \\
\hline I.Transfer Modes & & & 1.00 & & & & & & & & \\
\hline 2. Innovativeness & 39.12 & 58.42 & $-0.19^{*}$ & 1.00 & & & & & & & \\
\hline 3. Proactiveness & 2.61 & 3.39 & $0.26^{* *}$ & $0.33^{* *}$ & 1.00 & & & & & & \\
\hline 4. Risk & 0.20 & 0.18 & $0.24^{* *}$ & 0.03 & -0.08 & 1.00 & & & & & \\
\hline 5. R\&D Intensity (Log) & 6.6 & 0.70 & 0.02 & 0.03 & -0.05 & 0.03 & 1.00 & & & & \\
\hline 6.Age (Log) & 0.84 & 0.30 & -0.01 & $-0.20^{*}$ & $0.15^{*}$ & -0.09 & -0.07 & 1.00 & & & \\
\hline 7. Previous Relationship & 0.40 & 0.49 & -0.12 & 0.01 & -0.08 & -0.07 & -0.13 & -0.06 & 1.00 & & \\
\hline 8. Exclusive Licensing & 0.80 & 0.40 & -0.04 & 0.11 & -0.05 & -0.07 & -0.10 & $-0.17^{*}$ & $0.53^{* *}$ & 1.00 & \\
\hline 9. Cluster & 0.74 & 0.44 & 0.01 & 0.10 & -0.11 & 0.01 & 0.03 & -0.09 & -0.04 & -0.11 & 1.00 \\
\hline
\end{tabular}

$\mathrm{N}=171, \mathrm{p}^{*<}<.05 ; * * \mathrm{p}<.01$

Table 3. Means, Standard Deviations, and Correlation Matrix.

ISSN: 07 I8-2724. (http://www.jotmi.org)

Journal of Technology Management \& Innovation (c) Universidad Alberto Hurtado, Facultad de Economía y Negocios. 


\begin{tabular}{|c|c|c|c|c|c|}
\hline & & Model I & Model 2 & & \\
\hline \multirow{7}{*}{$\begin{array}{l}\text { Reference Group } \\
\text { Licensing }\end{array}$} & & Hypothesis I & Hypothesis 2 & & \\
\hline & Variables & B (Std Error) & $\operatorname{Exp} B$ & B (Std Error) & $\operatorname{Exp} B$ \\
\hline & Controls & & & & \\
\hline & Age (log) & $0.69(0.50)$ & 2.00 & $0.75 *(0.53)$ & 1.95 \\
\hline & Location & $0.67^{* *}(0.83)$ & 0.55 & $1.04^{* *}(0.93)$ & 2.54 \\
\hline & Previous Relationship & $-0.15(0.53)$ & 0.86 & $-0.29(0.55)$ & 0.65 \\
\hline & R\&D Intensity (log) & $-0.38(0.53)$ & 0.68 & $-0.08(0.55)$ & 0.64 \\
\hline \multirow[t]{4}{*}{$\begin{array}{l}\text { Panel I } \\
\text { Contract Research }\end{array}$} & Licensing Term & $-0.60^{* *}(0.57)$ & 0.55 & $0.70^{* *}(0.57)$ & 0.57 \\
\hline & Innovativeness & $-0.54^{* *}(0.64)$ & 1.95 & & \\
\hline & Proactiveness & & & $0.75^{* *}(0.47)$ & 1.80 \\
\hline & Controls & & & & \\
\hline \multirow[t]{3}{*}{ Control Variables } & Age & $0.260(0.50)$ & 0.80 & $-0.07(0.48)$ & 0.93 \\
\hline & Location & $0.45(0.83)$ & 0.60 & $0.63(0.77)$ & 0.45 \\
\hline & Previous Relationship & $-0.65^{* *}(0.55)$ & 0.51 & $-0.83^{* *}(0.44)$ & 1.88 \\
\hline \multirow[t]{4}{*}{$\begin{array}{l}\text { Panel } 2 \\
\text { Consulting }\end{array}$} & $\begin{array}{l}\text { R\&D Intensity (log) } \\
\text { Licensing Term }\end{array}$ & $\begin{array}{l}0.73^{* *}(0.53) \\
0.01(.01) \\
\end{array}$ & $\begin{array}{l}2.11 \\
1.01 \\
\end{array}$ & $\begin{array}{l}1.05^{* * * * *}(0.48) \\
0.00(0.01)\end{array}$ & $\begin{array}{l}2.88 \\
1.00\end{array}$ \\
\hline & Innovativeness & $-0.5 I^{*}(0.47)$ & 1.37 & & \\
\hline & Proactiveness & & & $-0.86^{* *}(0.49)$ & 2.36 \\
\hline & $\begin{array}{l}\text { X2 } \\
\text { Sig. } \\
\text { Cox \& Snell }\end{array}$ & & $\begin{array}{l}25.37 \\
.09 \\
0.17\end{array}$ & & $\begin{array}{l}27.52 \\
0.05 \\
0.21\end{array}$ \\
\hline
\end{tabular}

Note. Table entries are logistic regression coefficients.

Standard errors are in parentheses; $\mathrm{n}=171$ (27 out of the total I 98 DBFs did not have university links). $*_{p}<.10,{ }^{* *} \mathrm{p}<.05,{ }^{* * * *} \mathrm{p}<.001$.

Table 4. Multinomial Logistic Regression with Licensing as Reference Category.

DBFs have a predilection to sponsor faculty research and hire academic scientists as consultants. These two technology transfer modes use informal communication channels such as social interactions to disseminate knowledge (Link, Siegel, and Bozeman, 2007). The dissemination of knowledge through frequent contact allows DBFs to gain access to and leverage faculty members' absorptive capacity (Cohen and Levinthal, 1990), which includes a scientist's ability, educational background, and job-related skills (Minbaeva, et al., 2003). When participating in technology transfer, non-innovative DBFs rely on faculty members to provide them with access to new research and discoveries (Lee, 2000). Close frequent contact facilitates the development of a common language and trust between partners (Mowery, Oxley, and
Silverman, 2002; Ring and Van de Ven, 1994). These relational factors engender knowledge transfer, learning, and the creation of knowledge (Nonaka and von Krogh, 2009).

Second, proactive DBFs seek to acquire knowledge to create an advantage now and sustain it in the future. Hypothesis 2 states that proactive DBFs should select technology transfer modes that promote their ambidexterity by allowing them to explore new technologies by sponsoring contract research and exploiting their existing capabilities via licensing. Drug development is an arduous task. To adapt to continuously changing environmental conditions, DBFs should exploit existing competencies and explore new ones because these two aspects of organizational learning are inseparable 


\begin{tabular}{|c|c|c|c|c|c|}
\hline & & Model 3 & Model 2 & & \\
\hline \multirow{2}{*}{$\begin{array}{l}\text { Reference Group } \\
\text { Licensing }\end{array}$} & & Hypothesis 3 & Full Model & & \\
\hline & Variables & B (Std Error) & Exp B & B (Std Error) & Exp B \\
\hline \multirow[t]{4}{*}{ Control Variables } & Age (log) & $0.67(0.55)$ & 1.95 & $0.84^{* *}(0.57)$ & 2.13 \\
\hline & Location & $0.93^{* *}(0.84)$ & 2.54 & $1.53^{* * * *}(0.98)$ & 2.42 \\
\hline & Previous Relationship & $-0.4 I(0.55)$ & 0.65 & $-0.08(0.59)$ & 0.02 \\
\hline & R\&D Intensity (log) & $-0.43(0.57)$ & 0.65 & $0.3 I(0.62)$ & 0.24 \\
\hline \multirow[t]{4}{*}{$\begin{array}{l}\text { Panel I } \\
\text { Contract Research }\end{array}$} & Licensing Term & $-0.55^{*}(0.59)$ & 0.57 & $-0.104(0.70)$ & 0.02 \\
\hline & Innovativeness & & & $-0.86(0.97)$ & 0.80 \\
\hline & Proactiveness & & & $0.97^{* * * *}(.061)$ & 2.53 \\
\hline & Risk Taking & $0.42^{* *}(0.53)$ & 1.65 & $0.45^{*}(0.56)$ & 2.24 \\
\hline \multirow[t]{3}{*}{ Control Variables } & Age & $0.06(0.49)$ & 1.06 & $0.35(0.53)$ & 0.70 \\
\hline & Location & $0.57(0.79)$ & 1.78 & $1.33^{* * * *}(0.86)$ & 3.78 \\
\hline & Previous Relationship & $-0.6 I^{*}(0.50)$ & 0.53 & $-1.16^{* * *}(0.56)$ & 0.31 \\
\hline \multirow[t]{4}{*}{$\begin{array}{l}\text { Panel } 2 \\
\text { Consulting }\end{array}$} & $\begin{array}{l}\text { R\&D Intensity (log) } \\
\text { Licensing Term }\end{array}$ & $\begin{array}{l}1.00^{* *}(0.50) \\
0.01(.01)\end{array}$ & $\begin{array}{l}2.74 \\
1.01\end{array}$ & $\begin{array}{l}1.5 I^{* * * * *}(0.56) \\
0.64(0.7 \mathrm{I})\end{array}$ & $\begin{array}{l}0.22 \\
1.90\end{array}$ \\
\hline & Innovativeness & & & $-0.37(0.75)$ & 1.46 \\
\hline & $\begin{array}{l}\text { Proactiveness } \\
\text { Risk Taking }\end{array}$ & $0.67^{*}(0.48)$ & 1.51 & $\begin{array}{l}0.43(0.55) \\
0.33(0.5 \mathrm{I})\end{array}$ & $\begin{array}{l}2.36 \\
1.39\end{array}$ \\
\hline & $\begin{array}{l}\text { X2 } \\
\text { Sig. } \\
\text { Cox \& Snell }\end{array}$ & & $\begin{array}{l}27.18 \\
.03 \\
0.22\end{array}$ & & $\begin{array}{l}32.32 \\
0.05 \\
0.30\end{array}$ \\
\hline
\end{tabular}

Note. Table entries are logistic regression coefficients. Standard errors are in parentheses; $\mathrm{n}=171$ ( 27 out of the total $198 \mathrm{DBFs}$ did not have university links). $*_{\mathrm{p}}<.10, *^{*} \mathrm{p}<.05, * * * \mathrm{p}<.001$.

Table 5. Multinomial Logistic Regression with Licensing as Reference Category.

(Floyd and Lane, 2000). Although these two learning modes may appear contrary to each other, DBFs have to find a balance to prevent their capabilities from becoming too rigid or outdated. The findings show that proactive DBFs select licensing and sponsored contract research, which both support profit- and capability-generation.

Third, selecting transfer modes that involve a high level of knowledge conversion is risky. Hypothesis 3 declares that risk-taking DBFs would be more likely to select sponsored contract research and licensing over consulting agreements. Contrary to the initial assertion, the results suggest that consulting agreements might be more of a risk than licensing. When participating in consulting agreements, a DBF hires a scientist to create new knowledge when solving a problem; however, there is no guarantee that (a) the firm can implement the solution and (b) the solution will work. Licenses consist of tangible knowledge that a DBF's scientists can explore. Consulting agreements and sponsored contracts involve tacit knowledge that resides in the scientist's mind and is difficult to articulate. Unlike licenses, there is no blueprint that helps a DBF's employees make sense of contract research outcomes and consulting advice. A solution is viable only to the extent that a DBF's employees can make sense of and integrate it. This discussion now offers scholarly implications and implications of how this study influences existing transfer practices. 


\section{Implications}

\section{Theoretical implications}

This paper puts forth two theoretical implications that highlight DBFs' growth. The first theoretical implication highlights an implicit assumption, in the current study, that university technology transfer supports a DBF's growth and development. When DBFs participate in technology transfer with universities, they are outsourcing an R\&D activity. Grimpe and Kaiser (2010) claimed that outsourcing can be detrimental to a firm that outsources too many services to a single source. The current study found that non-innovative DBFs use university knowledge as a substitute for their lack of absorptive capacity. Their reliance might lead to their inability to develop an internal knowledge base. A firm's survival, growth, and profitability depend on its ability "to establish one or more widely and relatively impregnable 'bases' from which it can adapt and extend its operations in an uncertain, changing, and competitive world" (Penrose, 1995, p. 137). Conversely, innovative firms have more control of the resources they need to survive. Research has revealed that the ability to control resources improves survival rates and the ability to exert influence over dependent firms (Alexy, George, and Salter, 2013). For non-innovative DBFs, too much reliance on university faculty might negatively influence their ability to develop technological and scientific stocks of knowledge that serve as a platform for growth and development.

The second implication describes how a DBF might enhance its attractiveness as an alliance partner by selecting a specific technology transfer mode. A DBF's participation in specific collaborations influences network actors' perceptions of its capabilities (Baum, Calabrese, and Silverman, 2000). For example, when a DBF has prior experience developing a license, this prior experience sends a signal to potential partners that this firm can successfully develop a product from a patent (Coombs and Deeds, 2000). Potential partners recognize that the amount (and type) of new drugs in a firm's research pipeline predicts the future potential value of the company's scientific capabilities. Selecting a transfer mode might enhance a DBF's legitimacy with potential collaboration partners. Many DBFs lack legitimacy as collaboration partners because they suffer from the liabilities of newness and smallness (Bruderl and Schussler, 1990; Stinchcombe, 1965). New and small firms will have legitimacy problems until they are perceived as legitimate members of the community (Hannan and Freeman, 1989). Legitimacy is an important resource that firms can leverage to gain access to resources that are critical to firm growth (Zimmerman and Zeitz, 2002). Selecting a favorably perceived technology transfer mode might enable a DBF to enhance its legitimacy and gain access to resources and partnerships.

\section{Managerial implications}

A managerial implication draws attention to the role that transaction costs play in the transfer mode selection process. Transaction costs are costs that arise when purchasing a product or service (Thouin, Hoffman, and Ford, 2009). Transaction cost economics (TCE) predicts that DBFs will select the mode of university technology transfer based on the total costs of the activity: production costs and transaction costs, which include monitoring, controlling, and contract enforcement costs (Holcomb and Hitt, 2007). The goal is to select the option with the lowest transaction costs.

When assessing technology transfer modes, it may be necessary for managers to include transaction costs because university research contains a high degree of tacitness, which hinders research and technology transfer (Howells, 2008). A DBF's employees must make sense of the knowledge in order to use it. To do so, managers may assign scientists to work closely with a university faculty member (Agarwal, 2006) to ensure that the firm can acquire and replicate the knowledge (Williams, 2007). Since DBFs have limited slack resources, other projects may fail to achieve important milestones because their key scientists have been reassigned to a technology transfer project. Furthermore, new routines may be needed to integrate the new knowledge into the firm's R\&D processes. Creating new routines as well as reassigning scientists between projects are transaction costs.

In contractual modes of university technology transfer such as sponsored contract research, intellectual property issues often arise from misunderstandings about each partner's contribution to the research (Mukherjee et al., 20I2). Intellectual property disputes can lead to prolonged legal battles that could adversely affect a DBF's already weak cash position (Shane, 2002). Contract monitoring, court costs, and legal fees are transaction costs that have the potential to undermine a DBF's ability to survive as an independent entity. Although university knowledge is valuable, there are transaction costs associated with acquiring and using it. Another implication is that a DBF might benefit from tracking the costs associated with brining university knowledge into the firm and then using this information to create estimates of the transaction costs associated with each mode of technology transfer. Once the estimates have been established, managers can consider the strategic benefits as well as estimated transfer costs when selecting a university technology transfer mode.

\section{Study Limitations and Future Research}

There are two limitations of this study. First, interviewing UTTO directors and reviewing university-industry studies led me to include sponsored contracts, consulting arrange- 
ments, and licensing agreements as transfer modes. Broadening the selections of transfer modes might enhance the depth of the analysis. Second, focusing on a single industry that has unique challenges and constraints may limit the generalizability of the current findings. However, these findings might also apply to small and new firms that participate in a high level of outsourcing or alliances and work closely with universities.

In the future, researchers might explore how perceptions influence a DBF's participation in a specific technology transfer mode. Additional insight might be gained by conducting a comparative analysis of whether the selection of a technology transfer mode changes when there are perceptual differences between internal and external stakeholders. In addition, future research might seek to include advisory board participation and joint research projects on the list of technology transfer modes. This research would establish a new avenue that scholars can use to explore university-industry relationships due to the limited exploration (Stephan and Everhart, 1998; Tornatzky, Waugaman, and Gray, 1999) of these two university transfer modes.

\section{Conclusion}

The current study was a novel attempt to initiate a discussion about how EO influences a DBF's participation in a specific technology transfer mode. The findings reveal that innovative DBFs might be more likely to select licensing, proactive DBFs focus on selecting transfer modes that support their ambidexterity, and risk-taking DBFs are drawn to technology transfer modes that rely heavily on academic scientists' highly tacit knowledge. There may be some concerns regarding the generalizability of the finds and the exclusion of some technology transfer modes. Despite the concerns, this study offers insight into the strategic choices DBFs make when seeking to bring external knowledge into the firm.

\section{References}

ABBEY, A., Dickson, J. (1983). R\&D work climate and innovation in semiconductors. Academy of Management Journal, 26(2), 362-368.

AGARWAL, S., Ramaswami, S.N. (1992). Choice of foreign market entry mode: Impact of ownership, location and internalization factors. Journal of International Business Studies, 23(I), I-27.

AGRAWAL, A. (2006). Engaging the inventor: Exploring licensing strategies for university inventions and the role of latent knowledge. Strategic Management Journal, 27(I), 6379.

AHUJA, G. (2000). The duality of collaboration: inducements and opportunities. Strategic Management Journal, 2 I (3), 3 I7343.

ALEXY, O., George, G., Salter,A. (20I3). Cui bono? The selective revealing of knowledge and its implication for innovative activity. Academy of Management Journal, 28(2), 270-29l.

ASTLEY,W.G.,Van de Ven, A.H. (1983). Central perspectives and debates in organization theory. Administrative Science Quarterly, 28(2), 245-273.

BARCLAY, S., Todd, C., Finlay, I., Grande, G.,Wyatt, P. (2002). Not another questionnaire! Maximizing the response rate, predicting non-response and assessing non-response bias in postal questionnaire studies of GPs. Family Practice, 19(I), I05-III.

BARTHOLOMEW, S., Smith, A. (2006). Improving survey response rates from chief executive officers in small firms:The importance of social networks. Entrepreneurship Theory and Practice, 30(I), 83-96.

BAUM, A.C., Calabrese, T., Silverman, B. (2000). Don't go it alone: Alliance network composition and startups' performance in Canadian biotechnology. Strategic Management Journal, 2 I (3), 267-294.

BAUM, M., Schwens, C., Kabst, R. (20I I).A typology of international new ventures: Empirical evidence from high-technology industries. Journal of Small Business Management, 49(3), 305-330.

BAUM, J.A., Silverman, B.S. (2004). Picking winners or building them? Alliance, intellectual, and human capital as selection criteria in venture financing and performance of biotechnology startups. Journal of Business Venturing, I9(3), 4 I I-436.

ISSN: 07 I8-2724. (http://www.jotmi.org) 
BERCOVITZ, J., Feldmann, M. (2006). Entrepreneurial universities and technology transfer: A conceptual framework for understanding knowledge-based economic development. Journal of Technology Transfer, 3I(I), I75-I88.

BIERLY, P.E., Gallagher S. (2007). Explaining alliance partner selection: Fit, trust and strategic expediency. Long Range Planning, 40(2), I34-I 53.

BLAU, P.M. (1977). Inequality and Heterogeneity. Free Press, New York.

BOURGEOIS, L.J. (1984). Strategic management and determinism. Academy of Management Review, 9(4), 586-596.

BRUDERL, J., Schussler, R. (1990). Organizational mortality: The liabilities of newness and adolescence. Administrative Science Quarterly, 35(3), 530-547.

CASPER, S. (2007). How do technology clusters emerge and become sustainable? Social network formation and interfirm mobility within the San Diego biotechnology cluster. Research Policy, 36(4), 438-455.

CHIESA, V., Chiaroni, D. (2005). Industrial Clusters in Biotechnology: Driving Forces, Development Processes and Management Practices. Imperial College Press, London.

CHILD, J. (1972). Organizational structure, environment, and performance: The role of strategic choice. Sociology, 6(I), $\mathrm{I}-22$.

COCKBURN, I.M., Henderson, R.M. (1998). Absorptive capacity, coauthoring behavior, and the organization of research in drug discovery. The Journal of Industrial Economics, 46(2), I57-I82.

COHEN,W.M., Levinthal, D.A. (1990). Absorptive capacity:A new perspective on learning and innovation. Administrative Science Quarterly, 35(I) I28-152.

COHEN,W.M., Nelson, R.R., Walsh, J.P. (2002). Links and impacts: Survey results on the influence of public research on industrial R\&D. Management Science, 48(I), I-23.

CONTRACTOR, F., Ra, W. (2002). How knowledge attributes influence alliance governance choices: $A$ theory development note. Journal of International Management, 8(I), I I27.

COOMBS, J.E., Bierly III, P.E., Gallagher, S. (20I2). The impact of different forms of IPO firm legitimacy on the choice of alliance governance structure. Journal of Management \& Organization 18(4), 516-536.
COOMBS, J.E., Deeds, D.L. (2000). International alliances as sources of capital: Evidence from the biotechnology industry. The Journal of High Technology Management Research, II (2), 235-253.

COVIN, J.G., Slevin, D.P. (1989). Small firms in hostile and benign environments. Strategic Management Journal, 10(I), 75-87.

CYERT, R., Goodman, P.S. (1997). Creating effective university-industry alliances: An organizational learning perspective. Organizational Dynamics, 25(4), 45-57.

DAFT, R. (1989). Organizational Theory and Design. West, St. Paul.

DECAROLIS, D.M. (2003). Competencies and imitability in the pharmaceutical industry:An analysis of their relationship with firm performance. Journal of Management, 29(I), 27-50.

DECAROLIS, D.M., Deeds, D.L. (1999). The impact of stocks and flows of organizational knowledge on firm performance: An empirical investigation of the biotechnology industry. Strategic Management Journal, 20(10), 953-968.

DECHENAUX, E., Thursby, J. and Thursby, M. (2009). Shirking, sharing risk and shelving: The role of university license contracts. International Journal of Industrial Organization, $27(1), 80-91$.

DEEDS, D.L. (200I). The role of R\&D intensity, technical development and absorptive capacity in creating entrepreneurial wealth in high technology start-ups. Journal of Engineering and Technology Management, I8(I), 29-47.

DESS, G.G., Lumpkin, G.T., Covin, J.G. (1997). Entrepreneurial strategy making and firm performance:Tests of contingency and configuration models. Strategic Management Journal, I8(9), 677-695.

D'ESTE, P., Perkmann, M. (20I I). Why do academics engage with industry: The entrepreneurial university and individual motivations. Journal of Technology Transfer, 36(9), 3 I6-339.

DILLMAN, D.A. (1978). Mail and Telephone Surveys:The Total Design Method. John Wiley \& Sons, New York.

DONALDSON, L. (200I). The Contingency Theory of Organizations. Sage Publishing, London.

EISENHARDT, K.M. (1989). Agency theory: An assessment and review.Academy of Management Review, I4(I), 57-74. 
ERNST \& YOUNG (2005). Competitive Growth and Growing Competition. www.ey.com/alumni/whitepapers [Accessed July 6, 2005]

ETZKOWITZ, H. (1998). The norms of entrepreneurial science: Cognitive effects of the new university-industry linkages. Research Policy, 27(8), 823-833.

FELDMAN, M., Feller, I., Bercovitz, J., Burton, R. (2002). Equity and the technology transfer strategies of American research universities. Management Science, 48(I), 105-121.

FLOYD, S.W., Lane, P.J. (2000). Strategizing throughout the organization: Managing role conflict in strategic renewal. Academy of Management Review, 25(I), I54-177.

GEORGE, G., Zahra, S., Wood, D.R. (2002). The effects of business-university alliances on innovative output and financial performance: A study of publicly traded biotechnology companies. Journal of Business Venturing, 17(6), 577-609.

GIERYN, T.F. (1983). Boundary-work and the demarcation of science from non-science: Strains and interests in professional interests of scientists. American Sociology Review, 48(6), 78I-95.

GRANT, R. (1996). Toward a knowledge-based theory of the firm. Strategic Management Journal, I7(7), I09-I 22.

GRIMPE, G., Kaiser, U. (20I0). Balancing internal and external knowledge acquisition:The gains and pains from R\&D outsourcing. Journal of Management Studies, 47(8), I483-I509.

GULATI, R. (1995). Does familiarity breed trust? The implications of repeated ties for contractual choice in alliances. Academy of Management Journal, 38(I), 85-I I 2.

GULATI, R. (1999). Network location and learning:The influence of network resources and firm capabilities on alliance formation. Strategic Management Journal, 20(5), 397-420.

HANNAN, M.T., Freeman, J. (1989). Organizational Ecology. Harvard University Press, Cambridge.

HITT, M.A., Hoskisson, R.E., Kim, H. (1997). International diversification: Effects on innovation and firm performance in product-diversified firms. Academy of Management Journal, 40(4), 767-798.

HOANG, H., Rothaermel, F.T. (2005). The effect of general and partner-specific alliance experience on joint R\&D project performance. Academy of Management Journal, 48(2), 332-345.

ISSN: 07 I8-2724. (http://www.jotmi.org)

Journal of Technology Management \& Innovation (c) Universidad Alberto Hurtado, Facultad de Economía y Negocios.
HOANG, H., Rothaermel, F.T. (20I0). Leveraging internal and external experience: Exploration, exploitation, and R\&D project performance. Strategic Management Journal, 3 I(7), 734-758.

HOLCOMB, T.R., Hitt, M.A. (2007). Toward a model of strategic outsourcing. Journal of Operations Management, 25(2), 464-48I

HOWELLS, J. (2008). New directions in R\&D: current and prospective challenges. R\&D Management, 38(3), 24I-252.

HOWELLS, J., Gagliardi, D., Malik, K. (2008). The growth and management of R\&D outsourcing: Evidence from UK pharmaceuticals. R\&D Management, 38(2), 205-219.

HUGHES, M., Morgan, R.E. (2007). Deconstructing the relationship between entrepreneurial orientation and business performance at the embryonic stage of firm growth. Industrial Marketing and Management, 36(5), 65I-66I.

JENSEN, R.A.,Thursby, J.G., Thursby, M.C. (2003). Disclosure and licensing of university inventions: "The best we can do with the $s^{* *}$ t we get to work with." International Journal of Industrial Organization, 2I (8), I 27 I- I 300.

JIANG, R.J., Tao, Q.T., Santoro, M. (2010). Alliance portfolio diversity and firm performance. Strategic Management Journal, 3 I (I0), I I36-I I 44.

KACHRA,A.,White. R. (2008). Know-how transfer:The role of social, economic/competitive, and firm boundary factors. Strategic Management Journal, 29(4), 425-445.

KIRKMAN, D.M., Phillips, N. (2012). Exploring and exploiting firm-level capabilities as predictors of biotechnology firms' participation in consulting agreements with university scientists. Advances in Business Research Journal, 5(I), 82-97.

KIRZNER, I.M. (1979). Perception, Opportunity, and Profit: Studies in the Theory of Entrepreneurship. University of Chicago Press, Chicago.

LEE, C., Lee, K., Pennings, J. (200 I). Internal capabilities, external networks, and performance: A study on technologybased ventures. Strategic Management Journal, 22(6-7), 615-640.

LEE, Y.S. (2000). The sustainability of university-industry research collaboration: An empirical assessment. The Journal of Technology Transfer, 25(2), I I I-I 33.

LEVINTHAL, D.A., March, J.G. (1993). The myopia of learning. Strategic Management Journal, I 4 (Winter Special Issue), $95-112$. 
LI, D., Eden, L.E., Hitt, M.A., Ireland, R.D. (2008a). Friends, acquaintances or strangers? Partner selection in R\&D alliances. Academy of Management Journal, 5I (2), 3I5-334.

LI,Y., Yi, L., Yi, D., Li, M. (2008b). Entrepreneurial orientation, strategic flexibilities and indigenous firm innovation in transitional China. International Journal of Technology Management, 4I, 223-246.

LIEBERMAN, M.B., Montgomery, D.B. (1988). First-mover advantages. Strategic Management Journal, 9, 4I-58.

LINDER, J.R., Murphy, T.H., Briers, G.E. (200I). Handling nonresponse in social science research. Journal of Agricultural Education, 42(I), 43-53.

LINK, A., Siegel, D.S., Bozeman, B. (2007). An empirical analysis of the propensity of academics to engage in informal university technology transfer. Industrial and Corporate Change, I6(4), 64I-655.

LUBATKIN, M.H., Simsek, Z., Ling, Y., Veiga, J.F. (2006). Ambidexterity and performance in small- to medium-sized firms: The pivotal role of top management team behavioral integration. Journal of Management, 32(5), 646-672.

LUMPKIN, G.T., Dess, G.G. (1996). Clarifying the entrepreneurial orientation construct and linking it to performance. Academy of Management Review, 2I (I), I35-I72.

LUMPKIN, G.T., Dess, G.G. (200I). Linking two dimension of entrepreneurial orientation to the firm performance:The moderating role of environment and industry life cycle. Journal of Business Venturing, I6(5), 429-45 I.

LYON, D.W., Lumpkin, G.T., Dess, G. (2000). Enhancing entrepreneurial orientation research: Operationalizing and measuring a key strategic decision making process. Journal of Management, 26(5), I055- 1085.

MARINO, L., Strandholm, K., Steensma, H.K., Weaver, K.M. (2002). The moderating effect of national culture on the relationship between entrepreneurial orientation and strategic alliance portfolio extensiveness. Entrepreneurship Theory and Practice, 2 I (2), I45-I60.

MARKMAN, G.D., Phan, P.H., Balkin, D.B., Gianiodis, P.T. (2005). Entrepreneurship and university based technology transfer. Journal of Business Venturing, 20(2), 24I-263.

MARKMAN, G.D., Siegel, D.S., Wright, M. (2008). Research and technology commercialization. Journal of Management Studies, 45(8), I 40 I - 423.
MCFADYEN, M.A., Cannella, A. (2004). Social capital and knowledge creation: Diminishing returns to the number and strength of exchange relationships.Academy of Management Journal, 47(5) 735-746.

MILLER, D. (1983). The correlates of entrepreneurship in three types of firms. Management Science, 297, 770-79I.

MINBAEVA, D., Torben, P., Björkman, I., Fey, L., Park, H.P. (2003). MNC knowledge transfer, subsidiary absorptive capacity, and HRM. Journal of International Business Studies, 34(6), 586-599.

MINNITI, M., Bygrave,W. (200I).A dynamic model of entrepreneurial learning. Entrepreneurship Theory and Practice, 25(3), 5- 16.

MOWERY, C., Oxley, J., Silverman, B. (2002). Two faces of partner-specific absorptive capacity: Learning and cospecialization in strategic alliances. In: Contractor, F.., Lorange, P. (Eds.), Cooperative Strategies and Alliances. Elsevier Science, Oxford. pp. 290-319.

MUKHERJEE, D., Gaur, A. S., Gaur, S. S., Schmid, F. (20I2). External and internal influences on R\&D alliance formation: Evidence from German SMEs. Journal of Business Research. Retrieved on November 14, 2012 from http://dx.doi. org/10.1016/j.jbusres.2012.01.009

NICHOLLS-NIXON, C.L., Woo, C.Y. (2003). Technology sourcing and output of established firms in a regime encompassing technological change. Strategic Management Journal, 24(7), 65 I-666.

NIOSI, J. (2003). Alliances are not enough explaining rapid growth in biotechnology firms. Research Policy, 32(5), 737750.

NONAKA, I., von Krogh, G. (2009). Tacit knowledge and knowledge conversion: Controversy and advancement in organizational knowledge creation theory. Organization Science, 20(3), 635-652.

NORBURN, D. (1989). The chief executive: A breed apart. Strategic Management Journal, IO(I), I-I5.

PENROSE, E.T. (1995). The Theory of the Growth of the Firm. Blackwell, London.

PÉREZ-LUÑO, A., Wiklund, J., Cabrera, R.V. (201 I). The dual nature of innovative activity: How entrepreneurial orientation influences innovation generation and adoption. Journal of Business Venturing, 26(5), 555-57I. 
PERKMANN, M., Walsh, K. (2007). University-industry relationship and open innovation: Towards a research agenda. International Journal of Management Reviews, 9(4), 259-280.

PERKMANN, M., Walsh, K. (2008). Engaging the scholar: Three forms of academic consulting and their impact on universities and industry. Research Policy, 37(10), | 884- I99|

PODSAKOFF, P. Organ, D. (1986). Self-reports in organizational research: Problems \& prospects. Journal of Management, I2(4), 53|-544.

POWELL, W.W., White, D.R., Koput, K.W., Owen $\square$ Smith, J. (2005). Network dynamics and field evolution: The growth of interorganizational collaboration in the life sciences. American Journal of Sociology, I I0(4), I I 32-1 205.

POWERS, J.B., McDougall, P.P. (2005). University start-up formation and technology licensing with firms that go public: A resource-based view of academic entrepreneurship. Journal of Business Venturing, 20(3), 29I-3I I.

PREVEZER, M. (1997). The dynamics of industrial clustering in biotechnology. Small Business Economics, 9(3), 255-27I.

RING, P.S.,Van de Ven,A.H. (1994). Developmental processes of cooperative interorganizational relationships. Academy of Management Review, 19(I), 90-II8.

ROTHAERMEL, F.T. Deeds, D.L. (2004). Exploration and exploitation alliances in biotechnology: A system of new product development. Strategic Management Journal, 25(3), 20I221.

ROTHAERMEL, F.T., Thursby, M. (2005). Incubator firm failure or graduation? The role of university linkages. Research Policy, 34(7), 1076-1090.

SANTORO, M., Gopalakrishnan, S. (200I). Relationship dynamics between university research centers and industrial firms:Their impact on technology transfer activities. Journal of Technology Transfer, 26(I-2), |63-17I.

SHAN,W., Song, J. (1997). Foreign direct investment and the sourcing of technological advantage: Evidence from the biotechnology industry. Journal of International Business Studies, 28(2), 267-284.

SHANE, S. (2002). Executive forum: university technology transfer to entrepreneurial companies. Journal of Business Venturing, I7(6), 537-552.

SILVERMAN, B.S., Baum, J.A.C. (2002). Alliance-based competitive dynamics in the Canadian biotechnology industry. Academy of Management Journal, 45(4), 79I-806.
SIMONIN, B.L. (1999). Ambiguity and the process of knowledge transfer in strategic alliances. Strategic Management Journal, 20(7), 595-623.

SINE,W.D., Shane, S., Di Gregorio, D. (2003). The halo effect and technology licensing: The influence of institutional prestige on the licensing of university inventions. Management Science, 49(4), 478-496.

STEPHAN, P.E., Everhart, S.S. (1998). The changing rewards to science: The case of biotechnology. Small Business Economics, I0(2), | $|4|-|5|$.

STINCHCOMBE,A.S. (1965). Social Structure and Organizations. In: March, J.G. (Ed.), Handbook of Organizations. Rand McNally, Chicago, IL. pp. I53-I 93.

STRAM,W., Elfring,T. (2008). Entrepreneurial orientation and new venture performance:The moderating role of intra- and extraindustry social capital. Academy of Management Journal, 5I(I), 97-III.

STUART,T.E., Ozdemir, S.Z., Ding,W. (2007).Vertical alliance networks:The case of the university-biotechnology pharmaceutical alliance chains. Research Policy, 36(4), 477-498.

SZULANSKI, G. (1996). Exploring internal stickiness: Impediments to the transfer of best practice within the firm. Strategic Management Journal, 17(Special Issue), 27-44.

TENG, B.S., Das, T.K. (2008). Governance structure choice in strategic alliances:The roles of alliance objectives, alliance management experience, and international partners. Management Decision, 46(5), 725-742.

THOMPSON, J.D. (1967). Organizations in Action. McGraw Hill, New York.

THOUIN, M. F., Hoffman, J. J., Ford, E.W. (2009). IT outsourcing and firm-level performance:A transaction cost perspective. Information \& Management, 46(8), 463-469.

TOOLE,A.A., Czarnitzki, D. (2007). Biomedical academic entrepreneurship through the SBIR program. Journal of Economic Behavior and Organization, 63(4), 716-738.

TORNATZKY, L., Waugaman, P., Gray, D. (1999). IndustryUniversity Technology Transfer: Models of Alternative Practice, Policy, and Program. Southern Technology Council, Research Triangle Park, NC.

VAN DE VRANDE, V., Vanhaverbeke,W., Duysters, G. (2009). External technology sourcing: The effect of uncertainty on governance mode choice. Journal of Business Venturing, 24(I), 62-80. 
WALTER, A., Auer, M., Ritter, T. (2006). The impact of network capabilities and entrepreneurial orientation on university spin-off performance. Journal of Business Venturing, 2I (4), 54I-567.

WANG, C.L. (2008). Entrepreneurial orientation, learning orientation, and firm performance. Entrepreneurship Theory, and Practice, 32(4), 635-657.

WIKLUND, J. (1999). The sustainability of the entrepreneurial orientation-performance relationship. Entrepreneurship Theory and Practice, 24(I), 37-48.

WIKLUND, J., Shepherd, D. (2003). Knowledge-based resources, entrepreneurial orientation, and the performance of small and medium-sized businesses. Strategic Management Journal, 24(|3), |307-|3|4.

WILLIAMS, C. (2007). Transfer in context: Replication and adaptation in knowledge transfer relationships. Strategic Management Journal, 28(3), 867-889.

WU, W.Y., Chang, M.L., Chen, C.W. (2008). Promoting innovation through the accumulation of intellectual capital, social capital, and entrepreneurial orientation. R\&D Management, 38(3), 265-277.

ZAHRA, S.A. (1996). Technology strategy and new venture performance: A study of corporate sponsored and independent biotechnology ventures. Journal of Business Venturing, I I (4), 289-32I.

ZAHRA, S.A., Nielsen, A.P., Bogner, W.C. (1999). Corporate entrepreneurship, knowledge, and competence development. Entrepreneurship:Theory and Practice, 23(3), 169-190.

ZIMMERMAN, M., Zeitz, G.J. (2002). Beyond survival:Achieving new venture growth by building legitimacy. Academy of Management Review, 27(3), 4I4-43I.

ZUCKER, L.G., Darby, M.R. (200I). Capturing technological opportunity via Japan's star scientists: Evidence from Japanese firms' biotech patents and products. The Journal of Technology Transfer, 26(I-2), 37-58.

ZUCKER, L., Darby, M.R., Torero, M. (2002). Labor mobility from academe to commerce. Journal of Labor Economic, 20(3), 629-660. 